\title{
Ebelik Öğrencilerinin Hasta Güvenliği Konusundaki Düşünceleri ve Tıbbi Hata Yapma Ĕgilimleri
}

\section{Midwifery Students' Thoughts on Patient Safety and Medical Failure Tendencies}

\author{
Rukiye Demir ${ }^{1 *}$, Damla Kızılca Çakaloz ${ }^{2}$, Ayten Taşpınar ${ }^{2}$, Ayden Çoban $^{2}$ \\ ${ }^{1}$ Sağlık Bakanlığı, Tekirdağ Devlet Hastanesi, Kadın Doğum Servisi, Tekirdağ, Türkiye \\ ${ }^{2}$ Adnan Menderes Üniversitesi Sağlık Bilimleri Fakültesi, Ebelik Bölümü, Aydın, Türkiye \\ e-mail: rukiye_kiymik@hotmail.com,damlakizilca@gmail.com, aytaspinar@yahoo.com, ayden.coban@adu.edu.tr \\ ORCID: 0000000346496403 \\ ORCID: 0000000159191364 \\ ORCID: 0000000179182457 \\ ORCID: 0000000221892488 \\ *Sorumlu Yazar / Corresponding Author: Sorumlu Yazar: Rukiye Demir ${ }^{1}$ \\ Gönderim Tarihi / Received: 04.10.2019 \\ Kabul Tarihi / Accepted: 30.04.2020 \\ DOI: $10.34087 /$ cbusbed.629419
}

\begin{abstract}
$\ddot{\mathbf{O z}}$
Giriş ve Amaç: Araştırma ebelik öğrencilerinin hasta güvenliği konusundaki düşünceleri ve tıbbi hata yapma eğilimlerini belirlemek amacıyla yapılmıştır.

Gereç ve Yöntemler: Analitik-kesitsel tipteki araştırma, 31 Ocak-28 Şubat 2018 tarihleri arasında bir devlet üniversitesinin sağlık bilimleri fakültesi 2., 3. ve 4. sınıf ebelik bölümü öğrencilerinde yürütülmüştür. Araştırmanın evrenini bu sınıflarda öğrenim gören öğrenciler $(n=284)$, örneklemini ise 201 öğrenci oluşturmuştur. Araştırmanın verileri "Tanıtıcı Bilgi Formu” ve "Hemşirelikte Tıbbi Hataya Eğilim Ölçeğì" ile toplanmıştır. Çalışmanın etik kurul onamı ve kurum izni alınmış olup öğrencilerin sözlü onamları alınmıştır. Verilerin istatistiksel analizi istatistik paket programı Statistical Package for the Social Sciences (SPSS) 24,0 kullanılarak, sayı, yüzde, ortalama ve standart sapma dağılımları hesaplanmış, Mann Whitney U ve Kruskal Wallis testleri yapılmıştır. Tüm analizler için p $<0,050$ değeri istatistiksel olarak anlamlı kabul edilmiştir.

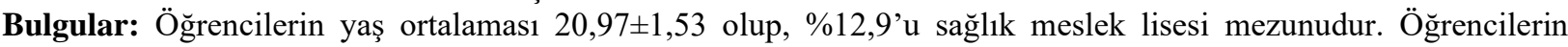
$\% 94,5$ 'i hasta güvenliği ve tıbbi hatalar konusunda daha önce eğitim aldığını, \%35,8'i klinik uygulamalarında tıbbi hata yaptığını, hata yapanların \%18,1'i hatayı rapor etmediklerini, \%46,8'i arkadaşlarının, \%50,2'si ebe ve hemşirelerin yaptıkları tıbbi hatalara şahit olduklarını belirtmiştir. Öğrencilerin Hemşirelikte Tıbbi Hataya Eğilim Ölçeğinden aldıkları toplam puan ortalaması $183,9 \pm 17,1$ olup tıbbi hata yapma eğilimlerinin düşük olduğu belirlenmiştir. İkinci sınıfta okuyan öğrencilerin ölçeğin “ilaç ve transfüzyon uygulamaları”, "hastane enfeksiyonları”, "düşmeler" ve "iletişim” alt boyut puan ortalamaları diğer sınıflarda ki öğrencilere göre ve 19-20 yaş grubundaki öğrencilerin ölçeğin "ilaç ve transfüzyon uygulamaları" ve "hastane enfeksiyonları" alt boyut puan ortalamaları diğer yaş gruplarına göre istatistiksel olarak daha yüksek bulunmuştur $(\mathrm{p}<0,005)$.

Sonuç: Öğrencilerin tıbbi hata yapma eğilimlerinin düşük olduğu, yaklaşık üçte birinin klinik uygulamalarında tıbbi hata yaptıkları ve bu hataların yaklaşık yarısını rapor ettikleri saptanmıştır. Öğrencilerin sık yaptıkları tıbbi hata konularına dikkat çekmek ve azaltmak için derslerde ve uygulamalarda tıbbi hatalar konusunda düzenli eğitimlerin verilmesi ve hasta güvenliği bilincinin oluşturulması, sık yapılan hatalarla ilgili rehberlerin hazırlanması önerilmektedir.
\end{abstract}

Anahtar Kelimeler: Ebelik öğrencisi, hasta güvenliği, tıbbi hata 


\begin{abstract}
Objective: The study was designed to determine midwifery students' perceptions of patient safety and their tendency to make medical malpractices.
\end{abstract}

Materials and Methods: The analytical-cross-sectional study was conducted between the 31st of January and 28th of February, 2018, at the 2nd, 3rd and 4th grade midwifery students of a public university. The universe of the study was students who studied in these classes $(n=284)$ and the sample was 201 students. The data of the research were collected by using "Questionnaire Form" and "Tendency to Medical Error in Nursing Scale". Ethics committee approval and institutional permission were obtained for the study, and verbal consent was obtained from the students. Statistical analysis of data Using statistical package program Statistical Package for the Social Sciences (SPSS) 24.0, number, percentage, mean and standard deviation distributions were calculated, Mann Whitney U and Kruskal Wallis tests were performed. For all analyzes, $\mathrm{p}<0.050$ was considered statistically significant

Results: The average age of students is $20.97 \pm 1.53$ and $12.9 \%$ of them are graduates of health vocational high schools. It was stated that $94.5 \%$ of the students had already received training on patient safety and medical malpractices, $35.8 \%$ had made any medical malpractices in their clinical practice, and $18.1 \%$ of those who made mistakes did not report an malpractices. $46.8 \%$ of the students were seen by their friends and $50.2 \%$ were witnessed by the midwives/nurses of medical malpractices, The mean score for Medical malpractice trend scale in nursing was found as $183.9 \pm 17.1$ of all subscales and the proneness to medical malpractices among midwife students was low. It was found that the Medical Malpractice Tendency Scale of the students who were read by the students affected the mean scores of "drug and transfusion applications", "hospital infections" and "falls" and "communication" subscales. And also "medication and transfusion applications" and "hospital infections" subscale scores were found to be affected by age groups $(\mathrm{p}<0.005)$.

Conclusion: It has been found that the tendency of students to make medical malpractice is low. It has been found that about one third of the students have made a medical malpractice in their clinical practice, and they reported a large majority of these errors, and almost all of them stated that medical staff could avoid medical malpractice in the clinic. Generally, in order to draw attention to these issues in practice, it is suggested to prepare patient safety awareness and increase sanctions by preparing regular trainings and to prepare guidelines about common malpractice. Key Words: Midwifery student, patient safety, medical malpractice

\section{Giriş}

Dünya'da hasta güvenliği kavramı 1990 yıllarının sonlarına doğru Amerika Birleşik Devletleri'nde Tıp Enstitüsü tarafından yayınlanan rapor ile birlikte kullanılmaya başlamıştır. $\mathrm{Bu}$ enstitü tarafından 1999 yılında yayınlanan "To Err is Human" başlıklı raporda her y1l 44000 ile 98000 kişinin tıbbi hatalar nedeniyle yaşamını yitirdiği, sağlık hizmetlerinin sunumu sırasında hatanın rutin olduğu ve hastaneye yatışların yaklaşık \%10'unda gerçekleştiği belirtilmiştir [1,2].

Hasta güvenliği sağlık hizmetinin temel bir ilkesidir ve sağlık sistemi içindeki güvensiz hareketlerin önlenmesi, azaltılması, aynı zamanda en iyi hasta sonuçlarına yol açacak en iyi uygulamaların kullanılması olarak tanımlanabilir [3, 4]. Güvenlik, sağlık sistemi performansında ve kalite yönetiminde birinci derecede önemli bir unsur olarak vurgulanmakta ve küresel çözümler içeren bir sorun olarak karşımıza çıkmaktadır. $\mathrm{Bu}$ nedenle, hasta güvenliği ve sağlık hizmetlerinin kalitesinin artırılması, dünya genelindeki sağlık hizmetleri için öncelikli bir konu olarak ortaya çıkmıştır $[5,6,7]$.

Günümüzde yaşanan bilimsel ve sosyal gelişmeler sağllk alanında da kendini göstermiş; sağlık hizmetini alanlar, en kısa sürede sağlıklarına kavuşmayı, tanı ve tedavilerinin doğru ve eksiksiz bir şekilde yapılmasını isterken bu süreçte yapılan uygulamalara ilişkin bilgi talep eder hale gelmelerini sağlamıştır [8]. Bu durum sağlık bakım profesyonelleri tarafından birçok klinik kararın baskı altında verilmesine, uygulamalarda yanlış ya da hataya, sonuç olarak ciddi yaralanmalara, hastanede kalış süresinin uzamasına, sakatlığa hatta kişinin ölümüne yol açabilmektedir $[9,10]$.

Sağlik hizmeti veren profesyoneller arasında ebeler ve hemşireler güvenli, yüksek kaliteli sağlık bakım hizmetlerinin temelini oluştururlar. Hasta ile daha uzun süre etkileşimde olduklarından dolayı diğer sağlık profesyonellerine göre, hasta güvenliğinin sağlanmasında önemli rol üstlenirler [11]. Ayrıca sağlık bakım hizmetlerinin sunumunda mevcut en iyi kanıtları klinik uygulamada kullanarak ortaya çıkması muhtemel birçok tıbbi hatayı ortadan kaldırabilirler [12].

Klinik ortam, öğrencilere gerçek ilaçlar ve öğrendikleri becerileri gerçek kişilerde uygulama imkânı sunmaktadır. Ancak geleceğin nitelikli profesyonelleri olarak ebelik öğrencilerinin teorik eğitimleri kadar bilgilerini beceriye dökecekleri klinik eğitimleri de önemlidir [13, 14]. Ancak öğrencinin hasta bireye herhangi bir uygulama yapması öğrenci için büyük bir stres kaynağıdır. Uygulama alanında yeni bir hasta ile karşılaşma ve bu hastaya ilk kez herhangi bir uygulama yapma öğrencilerde anksiyete ve korkuya neden olabilmekte ve öğrencilerin tıbbı hata yapmasına yol açabilmektedir $[14,15,16]$. Ayrıca öğrenciler yöneticilerinin ve öğretim elemanlarının tepkisinden korkma, suçlanma, cezalandırılma korkusu gibi sebeplerden dolayı hatalarını gizleme eğilimindedirler [17]. Bodur ve ark (2012)'nın ebelik ve hemşirelik son sınıf öğrencilerinin hasta güvenliği ve tıbbi hatalar hakkındaki bilgi ve tutumlarını değerlendirmek amacıyla yaptıkları çalışmada, öğrencilerin \%37'sinin stajları sırasında tıbbi hata yaptıklarını, yaptıkları tıbbi hataların \%29'unun rapor edilmediğini belirtmişlerdir [15]. 
Öğrencilerin tanık oldukları hataların saptanması amacıyla yapılan bir çalışmada, hataların \%20,4'ünün öğrenci hemşireler tarafindan yapıldı ̆ğ ve hataların \%3,8'inin rapor edilmediği bulunmuştur [18].

Dünya Sağlık Örgütü 2011 yılında diş hekimliği, tıp, ebelik, hemşirelik ve eczacılık alanlarındaki eğitim kurumlarındaki hasta güvenliği eğitimine yardımcı olmak için "World Health Organization Patient Safety Curriculum Guide for Medical Schools" başliklı rehberini yayınlamıştır. Dünya çapında hasta güvenliği eğitimi, ilkeleri ve yaklaşımları ile hasta merkezli bakım uygulamak üzere eğitilmiş öğrenciler yetiştirmeyi amaçlamaktadır [1]. Ayrıca sağlık çalışanlarının eğitiminde, hasta güvenliğini geliştirmede tam rol oynamak ve çalışma ortamlarına benzer durumları sağlayacak yeni eğitim programları ve yöntemlerinin kullanılmasını önermektedir [1, 19]. Hasta güvenliği yaklaşımlarının geliştirilmesi için tıbbi hataların neden ve nasıl geliştiğinin ortaya konması gerekmektedir. $\mathrm{Bu}$ çalışmada ebelik öğrencilerinin hasta güvenliği konusundaki düşünceleri ve tıbbi hata yapma eğilimlerinin belirlenmesi amaçlanmıştır.

\section{Materyal ve Metot}

\subsection{Araştırmanın Tipi}

Araştırma, analitik-kesitsel tipte olup, 31 Ocak- 28 Şubat 2018 tarihleri arasında yapılmıştır.

\subsection{Araştırmanın Evreni ve Örneklemi}

Araştırmanın evrenini bir devlet üniversitesinin sağlık bilimleri fakültesi ebelik bölümünün 2 ., 3 . ve 4 . sınıflarına kayıtlı 284 öğrenci oluşturmuştur. Araştırmanın örneklem hacmi; evreni bilinen örnekleme yöntemi ile (\%95 güven aralığı ve 0,5 örneklem hatası) hesaplanmış ve $\mathrm{n}=164$ bulunmuştur. Araştırmanın yapıldığı gün ve saatte sınıfta olan, araştırmaya katılmayı kabul eden tüm öğrenciler çalışmaya alınmıştır. Araştırma 201 öğrenci ile tamamlanmıştır. Uygulama için kliniğe henüz çıkmamış olan birinci sınıf öğrencileri araştırmanın dışında tutulmuştur.

\subsection{Verilerin Toplaması ve Değerlendirilmesi}

Araştırma verileri "Tanıtıcı Bilgi Formu" ve "Hemşirelikte Tıbbi Hataya Eğilim Ölçeği" ile toplanmıştır. Araştırmacılar tarafından literatüre [15, 20 , 21, 22] dayalı olarak hazırlanan veri toplama formu; öğrencilerin sosyo-demografik özelliklerini içeren üç, hasta güvenliği ve ilaç hataları konusundaki görüşlerini içeren 19 soru olmak üzere toplam 22 sorudan oluşmaktadır.

Hemşirelikte Tıbbi Hataya Eğilim Ölçeği (HTHEÖ); hasta bakımında görev alan ebe/hemşirelerin tıbbi hata yapmaya eğilim düzeylerini ölçmek amacıyla 2010 yılında Özata ve Altunkan tarafından geliştirilmiş, geçerlik ve güvenirliği test edilmiştir [20]. Ölçeğin tıbbi hataya eğilimleri değerlendiren 5 alt ölçeği ve 5'li Likert tipinde (1-hiç, 2-çok nadir, 3-zaman zaman, 4-genellikle ve 5-her zaman) 49 maddesi bulunmaktadır. Alt ölçekler; İlaç ve Transfüzyon Uygulamaları-18 madde, Hastane
Enfeksiyonlar1-12 madde, Hasta İzlemi ve Malzeme Güvenliği-9 madde, Düşmeler-5 madde, İletişim-5 madde olarak gruplandırılmıştır. Ölçek, her bir maddeye verilen yanıtların puanları toplanarak toplam puan ve alt boyut puanı üzerinden değerlendirilmektedir. Ölçekten alınan toplam puan yükseldikçe hemşirenin tıbbi hata yapmaya eğiliminin azaldı $\breve{1}$, puan azaldıkça da tıbbi hata yapmaya eğiliminin arttığı kabul edilmektedir. Araştırmamızda, HTHEÖ’nin “Hasta İzlemi ve Malzeme Güvenliği” alt ölçeği öğrenciler için uygun olmadığından dolayı çalışma dışında bırakılmıştır. Özata ve Altunkan'ın çalışmasında ölçeğin iç tutarlık katsayısı 0,95, alt grupların iç tutarlık 0,79 ile 0,95 arasında bulunmuştur [20]. Bu çalışmada ölçeğin iç tutarlılık kat sayısı 0,96, alt grupların iç tutarlılık 0,83 ile 0,93 arasında bulunmuştur.

Uygulama öncesinde araştırmacılar tarafından tüm öğrencilere araştırmanın amacı, veri toplama formunun ve ölçeğin nasıl doldurulacağı hakkında açıklama yapılmış ve öğrencilerden bilgilendirilmiş onam formuyla yazılı izinleri alınmıştır. Verilerin toplanması ortalama 15-20 dakika sürmüştür. Araştırmanın yürütülmesi için etik kurul izni (No:2018/1) ve Fakülte Dekanlığından kurum izni alınmıștır. Ayrıca araştırmanın yürütülmesinde kullanılan ölçek için yazarlardan yazılı izin alınmış ve Helsinki Deklarasyonu prensiplerine uygun davranılmıştır.

Verilerin istatistiksel analizi istatistik paket programı Statistical Package for the Social Sciences (SPSS) 24,0 kullanılarak yapılmıştır. Verilerin analizinde sayı, yüzde, ortalama ve standart sapma dağılımları hesaplanmış, Mann Whitney U ve Kruskal Wallis testleri yapılmıştır. Tüm analizler için $\mathrm{p}<0,050$ değeri istatistiksel olarak anlamlı kabul edilmiştir.

\section{Bulgular}

Ebelik öğrencilerinin hasta güvenliği konusundaki düşünceleri ve tıbbi hata yapma eğilimlerinin belirlenmesi amacıyla ebelik bölümünde okuyan 201 öğrenciyle yapılan bu çalışmada; çalışmaya katılan öğrencilerin yaş ortalaması 20,97士1,53 (min:19, max:33)'dür. Öğrencilerin \%39,3'ü 2. sinıf, \%26,9'u 3. sınıf ve \%33,8'i 4. sınıf 'tır. Öğrencilerin, \%12,9'u sağlık meslek lisesi mezunu olup, \%94,5'i hasta güvenliği ve tıbbi hatalar konularına yönelik eğitim aldıklarını bildirmişlerdir.

Çalışmaya katılan öğrencilerin \%35,8'i klinik uygulamaları sırasında herhangi bir tıbbi hata yaptıklarını, hata yapanların \%81,9'u yaptıkları hatayı rapor ettiklerini belirtmiştir. Hatalarını rapor etmeyen öğrenciler, rapor etmeme nedenlerini ise sırasıyla "asepsi kurallarının yeterince önemsenmediğini bildiğim için" “çalışanların/hocalarının tepkisinden çekindiğim için" ve “asepsi kurallarını bozmanın rapor edilmesi gerektiğini bilmiyordum" şeklinde ifade etmişlerdir (Tablo 1).

Çalışmaya katılan öğrencilerin \%46,8'i arkadaşlarının, $\% 50,2$ 'si ebe/hemşire/hekimlerin yaptıkları tıbbi hatalara şahit olduğunu, hata yapan arkadaşlarının \%11,7'sinin ve çalışanların \%9,9'unun hatayı rapor ettiklerini belirtmiştir. Ayrıca, öğrenciler arkadaşları ve çalışanlar 
Tablo 1. Öğrencilerin Tıbbi Hata ve Hasta Güvenliği ile İlgili Deneyimleri

\begin{tabular}{|c|c|c|}
\hline Deneyimler & n & $\%$ \\
\hline $\begin{array}{l}\text { Öğrencilerin Tıbbi Hata Yapma Durumu (n=201) } \\
\text { Evet } \\
\text { Hayır } \\
\text { Farkında değilim }\end{array}$ & $\begin{array}{l}72 \\
104 \\
25\end{array}$ & $\begin{array}{l}35,8 \\
51,7 \\
12,5\end{array}$ \\
\hline $\begin{array}{l}\text { Öğrencilerin Hatayı Rapor Etme Durumu }(\mathbf{n}=\mathbf{7 2}) \\
\text { Evet } \\
\text { Hayır }\end{array}$ & $\begin{array}{l}59 \\
13\end{array}$ & $\begin{array}{l}81,9 \\
18,1\end{array}$ \\
\hline $\begin{array}{l}\text { Öğrencilerin Hatayı Rapor Etmeme Nedenleri }(\mathbf{n}=\mathbf{1 5}) \\
\text { Asepsi kurallarının yeterince önemsenmediğini bildiğim için } \\
\text { Çalışanların ve hocalarımın tepkisinden çekindiğim için } \\
\text { Asepsi kurallarını bozmanın rapor edilmesi gerektiğini bilmiyordum }\end{array}$ & $\begin{array}{l}6 \\
6 \\
3\end{array}$ & $\begin{array}{l}40,0 \\
40,0 \\
20,0\end{array}$ \\
\hline $\begin{array}{l}\text { Arkadaşlarının Hatalarına Şahit Olma Durumu }(\mathbf{n}=\mathbf{2 0 1}) \\
\text { Evet } \\
\text { Hayır }\end{array}$ & $\begin{array}{l}94 \\
107\end{array}$ & $\begin{array}{l}46,8 \\
53,2\end{array}$ \\
\hline $\begin{array}{l}\text { Arkadaşlarının Hatayı Rapor Etme Durumu (n=94) } \\
\text { Evet } \\
\text { Hayır } \\
\text { Bilmiyorum }\end{array}$ & $\begin{array}{l}11 \\
80 \\
3\end{array}$ & $\begin{array}{l}11,7 \\
85,1 \\
3,2\end{array}$ \\
\hline $\begin{array}{l}\text { Arkadaşlarının En Çok Yaptığı Hata Türü }(\mathbf{n}=117) \\
\text { Asepsi Kurallarına Uyulmaması } \\
\text { İlaç Hataları } \\
\text { Hasta Kimliğinin Yanlış Tanılanması } \\
\text { Ciddi Sonuçlara Yol Açan Girişimler }\end{array}$ & $\begin{array}{l}62 \\
43 \\
8 \\
4\end{array}$ & $\begin{array}{l}53,0 \\
36,7 \\
6,7 \\
3,6\end{array}$ \\
\hline $\begin{array}{l}\text { Arkadaşlarının Yaptığı Hata Sonucunda Hastanın Zarar Görme Durumu (n=94) } \\
\text { Zarar Görmedi } \\
\text { Zarar Gördü } \\
\text { Bilmiyorum }\end{array}$ & $\begin{array}{l}68 \\
10 \\
16\end{array}$ & $\begin{array}{l}72,4 \\
10,6 \\
17,0\end{array}$ \\
\hline $\begin{array}{l}\text { Ebe/Hemşire/Hekimlerin Hatalarına Şahit Olma Durumu }(\mathbf{n}=\mathbf{2 0 1}) \\
\text { Evet } \\
\text { Hayır }\end{array}$ & $\begin{array}{l}101 \\
100\end{array}$ & $\begin{array}{l}50,2 \\
49,8\end{array}$ \\
\hline $\begin{array}{l}\text { Ebe/Hemşire/Hekimlerin Hatayı Rapor Etme Durumu (n=101) } \\
\text { Evet } \\
\text { Hayır } \\
\text { Bilmiyorum }\end{array}$ & $\begin{array}{l}10 \\
89 \\
2\end{array}$ & $\begin{array}{l}9,9 \\
88,1 \\
2,0\end{array}$ \\
\hline $\begin{array}{l}\text { Ebe/Hemşire/Hekimlerin Hatayı Rapor Etmeme Nedenleri }(\mathbf{n}=\mathbf{1 0 1})^{*} \\
\text { Hata/asepsi önemsenmediği/ciddi sonuçları olmayacağı için } \\
\text { Ortaya çıkacak sorunlardan başı ağrımasın/tepki almasın/yaptırımlardan korkmaları } \\
\text { Hasta hatayı fark etmediği için } \\
\text { Ayıplanmamak için } \\
\text { Alışkanlık olduğu için } \\
\text { Bilmiyorum }\end{array}$ & $\begin{array}{l}43 \\
22 \\
14 \\
10 \\
8 \\
4\end{array}$ & $\begin{array}{l}42,6 \\
21,8 \\
13,8 \\
9,9 \\
7,9 \\
4,0\end{array}$ \\
\hline $\begin{array}{l}\text { Ebe/Hemşire/Hekimlerin En Çok Yaptığı Hata Türü }(\mathbf{n}=\mathbf{1 1 3}) * \\
\text { Asepsi kurallarına uyulmaması } \\
\text { İlaç hataları } \\
\text { Hasta kimliğinin yanlış tanılanması } \\
\text { Ciddi sonuçlara yol açan girişimler } \\
\text { Hasta düşmesi }\end{array}$ & $\begin{array}{l}82 \\
17 \\
5 \\
6 \\
3\end{array}$ & $\begin{array}{l}72,5 \\
15,0 \\
4,4 \\
5,4 \\
2,7\end{array}$ \\
\hline $\begin{array}{l}\text { Ebe/Hemşire/Hekimlerin Yaptığı Hata Sonucunda Hastanın Zarar Görme } \\
\text { Durumu (n=101) } \\
\text { Zarar Görmedi } \\
\text { Zarar Gördü } \\
\text { Bilmiyorum }\end{array}$ & $\begin{array}{l}75 \\
12 \\
14\end{array}$ & $\begin{array}{l}74,2 \\
11,9 \\
13,9\end{array}$ \\
\hline
\end{tabular}

tarafından en çok yapılan hata türünün asepsi kurallarına uyulmaması (sırasıly \%53,0, \%72,5) ve ilaç hataları (sırasıyla $\% 36,7$ ve $\% 15,0$ ) olduğunu, arkadaşları tarafından yapılan hatalarda hastaların \%10,6'sının, çalışanlar da ise hastaların \%11,9'unun zarar gördüğünü belirtmiştir (Tablo 1).

Öğrenciler en fazla tıbbi hatayı deneyimsiz sağlık çalışanlarının $(\% 34,8)$ yaptığını belirtmişlerdir. Çalışmaya katılan öğrencilerin hemen hemen tamamı $(\% 98,5)$ tıbbi hataların engellenebileceğini düşünmektedir. Öğrenciler tıbbi hataların meydana gelmesindeki en önemli nedenleri sırasıyla; uzun çalışma saatleri nedeniyle oluşan yorgunluk ve stres $(\% 22,9)$, mesleki eğitimin yetersizliği $(\% 16,1)$ ve sağlık personelinin sayı olarak yetersiz olması $(\% 14,4)$ olarak belirtmişlerdir. Tıbbi hata yapılması durumunda tutumun ne olması gerektiğine ilişkin öğrencilerin \%53,6's1 "hataların mutlaka yetkili kişilere bildirilmelidir", \%24,9'u "sağlık çalışanları yapılan hataları hastaya açıklamalıdır" ve \%17,2'si "hata yapıldığında hastadan/yakınlarından özür dilenmelidir" ifadesini kullandıkları saptanmıştır. Öğrencilerin tıbbi hataları azaltmadaki önerileri sırasılla; "hastalara karşı daha duyarlı ve sorumlu davranılmalı/daha dikkatli ve özenli 
çalışılmalı” (\%20,3), ikinci önerileri “personel sayısını

“denetlemelerin artırılması gerekir/ciddi yaptırımlar artırmak" $(\% 14,2)$ ve üçüncü önerileri ise uygulanmalı” $(\% 13,9)$ şeklinde olmuştur (Tablo2).

Tablo 2. Öğrencilerin Tıbbi Hata ve Hasta Güvenliği ile İlgili Düşünceleri

\begin{tabular}{|c|c|c|}
\hline Düşünceler & n & $\%$ \\
\hline $\begin{array}{l}\text { En Çok Tıbbi Hata Yapma Olasılığı Olan Sağlık Çalışanları }(\mathbf{n}=\mathbf{2 5 9}) * \\
\text { Deneyimsiz Sağlık Çalışanları } \\
\text { Tüm Sağlık Çalışanları } \\
\text { Ebe, Hemşire } \\
\text { Hekim } \\
\text { Öğrenci Ebe ve Hemşireler }\end{array}$ & $\begin{array}{l}93 \\
78 \\
32 \\
31 \\
25\end{array}$ & $\begin{array}{l}35,9 \\
30,1 \\
12,4 \\
11,9 \\
9,7\end{array}$ \\
\hline $\begin{array}{l}\text { Tibbi Hataların Engellenebilme Durumu }(\mathbf{n}=\mathbf{2 0 1}) \\
\text { Evet } \\
\text { Hayır }\end{array}$ & $\begin{array}{l}198 \\
3\end{array}$ & $\begin{array}{l}98,5 \\
1,5\end{array}$ \\
\hline $\begin{array}{l}\text { Tibbi hataların meydana gelme nedenleri(n=772)* } \\
\text { Uzun çalışma saatleri nedeniyle yorgunluk, stres } \\
\text { Mesleki eğitiminin yetersiz olması } \\
\text { İletişim bozuklukları } \\
\text { Çalışan sağlık personelinin sayı olarak yetersiz olması } \\
\text { Ekip çalışmasının olmaması } \\
\text { Doktorların el yazılarının okunaklı olmaması } \\
\text { Sağlık hizmetlerinin karmaşı bir yapıda olması }\end{array}$ & $\begin{array}{l}177 \\
124 \\
122 \\
111 \\
95 \\
74 \\
69\end{array}$ & $\begin{array}{l}22,9 \\
16,1 \\
15,9 \\
14,4 \\
12,3 \\
9,5 \\
8,9\end{array}$ \\
\hline $\begin{array}{l}\text { Tıbbi hata durumunda tutum ne olmalıdır? }(\mathbf{n}=\mathbf{3 4 9}) * \\
\text { Hatalar mutlaka yetkili kişilere bildirilmelidir } \\
\text { Sağlık çalışanları yapılan hataları hastaya açıklamalıdır. } \\
\text { Hata yapıldığında hastadan/yakınlarından özür dilenmelidir } \\
\text { Ekip çalış̧asısının önemi vurgulanmalı } \\
\text { Hataya uğrayanlar sağlık çalışanlarını dava etmelidir }\end{array}$ & $\begin{array}{l}187 \\
87 \\
60 \\
11 \\
4\end{array}$ & $\begin{array}{l}53,6 \\
24,9 \\
17,2 \\
3,1 \\
1,2\end{array}$ \\
\hline $\begin{array}{l}\text { Tıbbi hataları azaltmadaki önerileriniz nelerdir? }(\mathbf{n}=\mathbf{2 8 1}) * \\
\text { Hastalara karşı daha duyarlı ve sorumlu davranılmalı/daha dikkatli ve özenli çalışılmalı } \\
\text { Personel sayısını artırmak } \\
\text { Denetlemelerin artıılması gerekir/ciddi yaptırımlar uygulanmalı } \\
\text { Çalışma saatlerini azaltmalı } \\
\text { Sik sık eğitimler verilmeli/sağlık çalışanları gelişmeleri/eğitim seviyeleri takip etmeli } \\
\text { Eğitimin kalitesi artmalı/iletş̧imle ilgili ders verilmeli/ eğitim esnasında daha fazla uygulamaya } \\
\text { çıkılmalı } \\
\text { Sağlık ekibi arasında iletişim geliştirilmeli/ekip çalışması olmalı } \\
\text { Doktorlar orderları bilgisayardan vermeli (kolay okunması için) } \\
\text { Gerektiğinde deneyimli çalışanlardan yardım istenmeli } \\
\text { Hastalarda eğitilmeli/ceza olmamalı korkularak bildirimlerin yapılmasını engellediği için }\end{array}$ & $\begin{array}{l}57 \\
40 \\
39 \\
37 \\
35 \\
32 \\
17 \\
14 \\
7 \\
3\end{array}$ & $\begin{array}{l}20,3 \\
14,2 \\
13,9 \\
13,2 \\
12,5 \\
11,4 \\
6,0 \\
5,0 \\
2,5 \\
1,0\end{array}$ \\
\hline
\end{tabular}

*Birden fazla yanıt verilmiştir

Öğrencilerin HTHEÖ alt boyutlarından aldıkları puan ortalamaları sırasıyla ilaç ve transfüzyon uygulamaları: $83,3 \pm 7,7$ hastane enfeksiyonları: $55,0 \pm 6,0$, düşmelerin önlenmesi: $22,7 \pm 2,5$ ve iletişim: $22,7 \pm 3,2$ 'dir. Hemşirelikte Tıbbi Hataya Eğilim Ölçeği toplam puan ortalaması: 183,9 $\pm 17,1$ olup (ölçeğin genel puan dağılım aralığı:40-200) öğrencilerin tıbbi hata yapma eğilimlerinin hem alt alanlarda hem de genelde düşük olduğu belirlenmiştir (Tablo 3).

Tablo 3. Öğrencilerin Hemşirelikte Tıbbi Hataya Eğilim Ölçeği alt grup puan ortalamaları (n=201)

\begin{tabular}{|l|l|l|l|l|}
\hline HTHEÖ Alt Grupları & $\begin{array}{l}\text { Dağılım } \\
\text { Aralı̆̆ı }\end{array}$ & $\begin{array}{l}\text { Madde } \\
\text { Sayısı }\end{array}$ & $\begin{array}{l}\text { Puan } \\
\text { Ortalamaları } \\
x \pm \text { SS }\end{array}$ & $\begin{array}{l}\text { Madde puan } \\
\text { Ortalamaları } \\
\boldsymbol{x} \pm \text { SS }\end{array}$ \\
\hline $\begin{array}{l}\text { İlaç ve Transfüzyon } \\
\text { Uygulamaları }\end{array}$ & $18-90$ & 18 & $83.3 \pm 7.7$ & $4.63 \pm 0.43$ \\
\hline Hastane Enfeksiyonları & $12-60$ & 12 & $55.0 \pm 6.0$ & $4.58 \pm 0.50$ \\
\hline Düşmelerin Önlenmesi & $5-25$ & 5 & $22.7 \pm 2.5$ & $4.54 \pm 0.51$ \\
\hline İletişim & $5-25$ & 5 & $22.7 \pm 3.2$ & $4.55 \pm 0.65$ \\
\hline HTHEÖ Genel & $\mathbf{4 0 - 2 0 0}$ & $\mathbf{4 0}$ & $\mathbf{1 8 3 . 9} \pm \mathbf{1 7 . 1}$ & $\mathbf{4 . 5 9} \pm \mathbf{0 . 4 2}$ \\
\hline
\end{tabular}

HTHE: Hemşirelikte Tıbbi Hataya Eğilim

Öğrencilerin bazı özelliklerine göre HTHEÖ alt boyutlarından aldıkları puan ortalamaları incelendiğinde; ögrencilerin HTHEÖ alt boyutlarından aldıkları puan ortalamaları bulundukları sinıflara göre $2 ., 3$. ve 4 . sınıflarda sırasıyla ilaç ve transfüzyon uygulamaları: $86,0 \pm 6,4 ; 80,6 \pm 8,7 ; 82,4 \pm 7,5$, hastane enfeksiyonlar1: $57,3 \pm 4,2 ; 52,4 \pm 6,8 ; 54,3 \pm 6,1$, düşmelerin önlenmesi:
$23,4 \pm 2,1 ; 22,0 \pm 2,7 ; 22,4 \pm 2,7$ ve iletişim: $23,4 \pm 2,3$; $22,0 \pm 3,8 ; 22,6 \pm 3,5$ 'dir (Tablo 4). Öğrencilerin HTHEÖ alt boyutlarından aldıkları puan ortalamaları yaş gruplarına göre 19-20, 21, 22-23 yaş gruplarında sırasıyla ilaç ve transfüzyon uygulamaları: $85,4 \pm 6,9 ; 82,7 \pm 8,1$; $81,5 \pm 7,8$, hastane enfeksiyonlar1: $56,4 \pm 5,1 ; 54,4 \pm 6,5$; $53,9 \pm 6,1$, düşmelerin önlenmesi: $23,2 \pm 2,3 ; 22,5 \pm 2,7$; 
$22,3 \pm 2,5$ ve iletişim: $22,9 \pm 2,9 ; 22,8 \pm 3,3 ; 22,3 \pm 3,6$ 'd1r (Tablo 4). Öğrencilerin HTHEÖ alt boyutlarından aldıkları puan ortalamaları mezun olunan liselere göre Sağlık meslek lisesi ve diğer liseler olmak üzere sırasıyla ilaç ve transfüzyon uygulamaları: $82,1 \pm 8,1 ; 83,5 \pm 7,7$, hastane enfeksiyonları: $54,3 \pm 6,0 ; 55,0 \pm 6,0$, düşmelerin önlenmesi: $22,4 \pm 3,2 ; 22,8 \pm 3,3$ ve iletişim: $22,4 \pm 3,2$; boyutlarından aldıkları puan ortalamaları konuyla ilgili eğitim alma durumlarına göre eğitim alan ve

almayanlarda sırasıyla ilaç ve transfüzyon uygulamaları: $83,4 \pm 7,7 ; 82,4 \pm 8,2$, hastane enfeksiyonları: 55,0 $\pm 5,9$; $54,8 \pm 6,9$, düşmelerin önlenmesi: $22,7 \pm 2,5 ; 22,9 \pm 2,6$ ve iletişim: $22,7 \pm 3,3 ; 23,7 \pm 1,4$ 'dür (Tablo 4). 22,8 $\pm 3,3$ 'dür (Tablo 4). Öğrencilerin HTHEÖ alt Tablo 4. Öğrencilerin Bazı Özelliklerine Göre Hemşirelikte Tıbbi Hataya Eğilim Ölçeği Puan Ortalamalarının Dağılımı (n=201)

\begin{tabular}{|c|c|c|c|c|c|c|}
\hline \multicolumn{2}{|l|}{ Özellikler } & $\mathbf{n}$ & $\%$ & $\begin{array}{l}\text { İlaç ve Transfüzyon } \\
\text { Uygulamaları } \\
\mathrm{X} \pm \mathrm{SS}\end{array}$ & $\begin{array}{l}\text { Hastane Enfeksiyonları } \\
\mathrm{X} \pm \mathrm{SS}\end{array}$ & $\begin{array}{l}\text { Düşmelerin Önlenmesi } \\
\mathrm{X} \pm \mathrm{SS}\end{array}$ \\
\hline Sinif & $\begin{array}{l}2 \\
3 \\
4\end{array}$ & $\begin{array}{l}79 \\
54 \\
68\end{array}$ & $\begin{array}{l}39,3 \\
26,9 \\
33,8\end{array}$ & $\begin{array}{l}86,00 \pm 6,43 \\
80,66 \pm 8,79 \\
82,47 \pm 7,51 \\
F=8,86 ; \mathbf{p}=\mathbf{0 , 0 0 0}\end{array}$ & $\begin{array}{l}57,31 \pm 4,25 \\
52,46 \pm 6,87 \\
54,39 \pm 6,19 \\
F=12,14 ; \mathbf{p}=\mathbf{0 , 0 0 0}\end{array}$ & $\begin{array}{l}23,46 \pm 2,17 \\
22,07 \pm 2,78 \\
22,41 \pm 2,70 \\
F=5,72 ; \mathbf{p}=\mathbf{0 , 0 0 4}\end{array}$ \\
\hline Yaş grubu & $\begin{array}{l}19-20 \\
21 \\
22-33\end{array}$ & $\begin{array}{l}73 \\
69 \\
59\end{array}$ & $\begin{array}{l}36,3 \\
34,3 \\
29,4\end{array}$ & $\begin{array}{l}85,46 \pm 6,97 \\
82,71 \pm 8,13 \\
81,55 \pm 7,85 \\
F=4,65 ; \mathbf{p}=\mathbf{0 , 0 1 1}\end{array}$ & $\begin{array}{l}56,45 \pm 5,15 \\
54,43 \pm 6,57 \\
53,94 \pm 6,14 \\
F=3,38 ; \mathbf{p}=\mathbf{0 , 0 3 6}\end{array}$ & $\begin{array}{l}23,27 \pm 2,34 \\
22,52 \pm 2,76 \\
22,32 \pm 2,59 \\
F=2,61 ; p=0,076\end{array}$ \\
\hline $\begin{array}{l}\text { Mezun } \\
\text { olunan lise }\end{array}$ & $\begin{array}{l}\text { SML* } \\
\text { Diğer }\end{array}$ & $\begin{array}{l}26 \\
175\end{array}$ & $\begin{array}{l}12,9 \\
87,1\end{array}$ & $\begin{array}{l}82,19 \pm 8,17 \\
83,54 \pm 7,73 \\
z=-0,79 ; p=0,425\end{array}$ & $\begin{array}{l}54,34 \pm 6,05 \\
55,12 \pm 6,04 \\
z=-0,45 ; p=0,649\end{array}$ & $\begin{array}{l}22,34 \pm 2,41 \\
22,79 \pm 2,61 \\
z=-1,07 ; p=0,284\end{array}$ \\
\hline $\begin{array}{l}\text { Konuyla } \\
\text { ilgili eğitim } \\
\text { alma } \\
\text { durumu }\end{array}$ & $\begin{array}{l}\text { Evet } \\
\text { Hayır }\end{array}$ & $\begin{array}{l}190 \\
11\end{array}$ & $\begin{array}{l}94,5 \\
5,5\end{array}$ & $\begin{array}{l}83,42 \pm 7,77 \\
82,45 \pm 8,22 \\
z=-0,47 ; p=0,634\end{array}$ & $\begin{array}{l}55,03 \pm 5,99 \\
54,81 \pm 6,99 \\
z=-0,16 ; p=0,866\end{array}$ & $\begin{array}{l}22,72 \pm 2,58 \\
22,90 \pm 2,66 \\
z=-0,30 ; p=0,763\end{array}$ \\
\hline
\end{tabular}

*SML: Sağlık meslek lisesi

Öğrencilerin okudukları sinıflara göre HTHEÖ Puan Ortalamalarının Dağılımı incelendiğinde, tüm sınıflarda ölçeğin alt alan puan ortalamalarının yüksek olduğu ancak "ilaç ve transfüzyon uygulamaları", "hastane enfeksiyonları”, “düşmelerin önlenmesi” alt boyut puan ortalamaları arasındaki farkın siniflar arasında istatistiksel olarak anlamlı olduğu (sırasıyla; $p=0,000$, $\mathrm{p}=0,000, \mathrm{p}=0,004)$, "iletişim" alt boyut puan ortalamaları arasındaki farkın ise sınırda olduğu bulunmuştur (Tablo 4). Yapılan ileri analizde bu farkın tüm alt alan puan ortalamalarında 2. sinıf ile 3. ve 4. siniflar arasında olduğu saptanmıştır. Çalışmamızda ikinci sınıfların tüm alanlarda hataya eğilimlerinin düşük olması bu sınıftaki öğrencilerin klinik uygulamaya daha az çıkmaları ve diğer sınıflara göre klinikte hastalara yönelik daha az girişim ve uygulama yapmalarından kaynaklanıyor olabileceği düşünülmektedir.

\section{Tartışma}

Ebelik öğrencilerinin hasta güvenliği konusundaki düşünceleri ve tıbbi hata yapma eğilimlerinin belirlenmesi amacıyla yapılan bu çalışmada; öğrencilerin büyük çoğunluğu $(\% 94,5)$ hasta güvenliği ve tıbbi hatalar konularına yönelik eğitim almıştır. Yıldız ve arkadaşlarının, mezuniyetin ve profesyonel sağlık personeli olarak çalışmanın hasta güvenliği üzerine etkinliğini belirlemek amacıyla yaptıkları çalışmada mezun olanların \%94,3'ü; son sinıf öğrencilerinin $\% 81,8$ 'i eğitimi süresince hasta güvenliği ile ilgili bilgilendirildiğini belirtmiştir [21]. Çalışmamızın bulguları bu çalışma bulgularıyla benzerdir. Her iki çalışmada öğrencilerin tıbbi hatalar ve hasta güvenliği konusunda eğitim alma oranlarının yüksek bulunması örgün eğitimde bu konulara önem verildiğini göstermektedir.

Çalışmaya katılan öğrencilerin yaklaşık üçte biri klinik uygulamaları sırasında herhangi bir tıbbi hata yaptıklarını belirtmiştir. Bodur, Filiz, Çimen ve Kapçı’nın, Ebelik ve Hemşirelik son sınıf öğrencilerinin hasta güvenliği ve tıbbi hatalar hakkındaki bilgi ve tutumlarının değerlendirilmesi amacıyla yaptıkları çalışmada ögrencilerin \%37'si stajları sırasında tıbbi hata yaptıklarını; Mankan, Bahçecioğlu ve Polat'ın hemşirelik ve ebelik öğrencilerinin tıbbi hata yapma eğilimlerini belirlemek amacıyla yaptıkları bir çalışmada ise intörn hemşirelik ve ebelik ögrrencilerinin \%10,4’ü eğitimleri süresince hasta güvenliğini tehlikeye atacak bir hata yaptığını belirtmiştir $[15,23]$. Çalışmamızda ögrencilerin tıbbi hata yapma oranları Bodur ve arkadaşlarının çalışma bulguları ile paralellik gösterirken, Mankan ve arkadaşlarının çalışmalarından daha yüksek bulunmuştur. Çalışmamıza katılan öğrencilerin tamamına yakını konuya yönelik eğitim aldıkları için hasta güvenliğine dikkat ettikleri ve tıbbi hata yapma oranlarının düştüğü düşünülebilir. Diğer yandan öğrencilerin klinik uygulamalarında bazı durumları hata olarak görmemeleri, yaptıkları hataları çalışanlardan ya da hocalarından çekinmelerinden dolayı açıkça söyleyememeleri ve ceza almaktan korkmaları gibi nedenlerden de kaynaklanmış olabileceği 
düşünülmektedir. Araştırmamızda çalışmaya katılan öğrencilerin büyük çoğunluğunun $(\% 81,9)$ yaptıkları hatayı rapor ettikleri belirlenmiştir. Bizim çalışmamızdan farklı olarak Bodur, Filiz, Çimen ve Kapçı'nın yaptıkları çalışmada; yapılan hataların sadece \%29'unun rapor edildiği bildirilmektedir [15]. Bu farkın çalışmamıza katılan öğrencilerin tamamına yakının konuya yönelik eğitim almalarından kaynaklanabileceği düşünülmektedir.

Çalışmaya katılan öğrencilerin yaklaşık yarısı arkadaşlarının ve ebe/hemşire/hekimlerin yaptıkları tıbbi hatalara tanık olduğunu, hata yapan arkadaşlarının çok azının hatayı rapor ettiklerini belirtmiştir. Benzer şekilde öğrenci hemşirelerle yapılan başka çalışmada da öğrencilerin üçte biri klinik uygulamalar sırasında hemşire, doktor ve öğrenci hemşirelerin yaptıkları tıbbi hataya tanık olduklarını, hataların rapor edilme oranının çok düşük olduğu belirtilmiştir [18]. Yine bir devlet hastanesinde hemşirelerin malpraktis algısını ve bu konudaki tutum ile davranışlarını değerlendirmek amacıyla yaptıkları bir çalışmada hemşirelerin üçte biri arkadaşlarının tıbbi hata yapma durumuna şahit olduklarını belirtmiștir [22]. Hata bildirim oranlarının meslek profesyonelleri ve öğrencilerde düşük olduğu görülmektedir ve bu sonuç, ülkemizde sağlık kuruluşlarında hasta güvenliği kültürünün yeterli olmadığını ile açıklanabilir.

Çalışmamıza katılan öğrenciler arkadaşları ve çalışanlar tarafından en çok yapılan hata türünün asepsi kurallarına uyulmaması ve ilaç hataları olduğunu belirtmiştir. Literatürde yapılan çalıșmalarda da ilaç uygulaması ile ilgili hatalar ve asepsi kurallarına uyulmamasının en çok görülen hata türü olduğu belirtilmiştir [23, 24, 25]. Bu çalışmada saptanan asepsi kurallarına uyulmama oranının yüksek olması literatürle kıyaslandığında yeni bir bulgu değildir. Sonuçlarımızın literatürle benzer şekilde yüksek olması ilaç uygulamalarının ve asepsi konularının örgün eğitimde ve uygulamalarda öğretim elemanları tarafından daha ağırlıklı ele alınması gerektiğini göstermesi açısından değerlidir.

Öğrenciler tıbbi hataların meydana gelmesindeki en önemli nedenleri sırasıyla; uzun çalışma saatleri nedeniyle oluşan yorgunluk ve stres, mesleki eğitimin ve sağlık personelinin sayı olarak yetersiz olması olarak belirtmişlerdir. Şahin ve Özdemir'in hemşirelerin tıbbi hata yapma eğilimlerinin incelenmesi amacıyla 210 hemşireyle yaptıkları çalışmada iş yükünün fazla, çalışan sayısının az olması ve çalışılan birimin sürekli değişmesi gibi faktörlerin tıbbi hatalara neden olduğu belirlenmiştir [26]. Mankan, Bahçecioğlu ve Polat'ın hemşirelik ve ebelik öğrencilerinin tıbbi hata yapma eğilimlerini incelemek amaciyla 202 intörn hemşirelik ve ebelik öğrencileriyle yaptıkları çalışmada da tıbbi hataların nedenleri stres, yorgunluk, iş yükünün fazla olması, mesleki bilginin yetersiz ve çalışma süresinin uzun olması olarak belirtilmiştir [23]. Araştırma sonuçlarımız literatür ile benzerlik göstermektedir. Klinik uygulamada denetimlerin sık yapılmasının yanı sıra niteliksel ve niceliksel değerlendirmelerle hataları önleme konusunda eğitimlerin düzenli aralıklarla sağlık personellerine verilip, onların ihtiyaçları doğrultusunda gereksinimlerinin belirlenmesi hataları önlemede önemli katkı sağlayacaktır [27].

T1bbi hata yap1lmas1 durumunda tutumun ne olmas1 gerekir? Sorusuna öğrencilerin yarıdan fazlası "hataların mutlaka yetkili kișilere bildirilmelidir" şeklinde, bazıları ise "sağlık çalışanları yapılan hataları hastaya açıklamalıdır" ve "hata yapıldığında hastadan/yakınlarından özür dilenmelidir" şeklinde cevap vermiştir. Yıldız ve ark.'nın yaptıkları bir çalışmada da öğrencilerin tamamına yakını hataya karşı gerekli kişilerin bilgilendirilmesi gerektiğini söylemiştir [21]. Bizim çalışmamızda literatüre benzer olarak yapılan tıbbi hataların bildirilmesi gerekliliğin belirtilmesi öğrencilerin konu hakkında yeterli sorumluluğa sahip olduğunu, tıbbi hatalar konusunda daha dikkatli ve özenli davranış sergileyeceklerini düşündürmektedir.

Öğrenciler en fazla tıbbi hatayı deneyimsiz sağlık çalışanlarının yaptığını ve tıbbi hataların önlenebileceğini belirtmişlerdir. Cebeci, Karazeybek, Sucu'nun öğrencilerin tanık oldukları hataların saptanması amacıyla yaptıkları çalışmada en çok hemşirelerin; Bodur, Filiz, Çimen ve Kapçı'nın çalıșmalarında en çok hekimlerin hata yaptığı belirlenmiştir [15, 18]. Çalışmamızda öğrencilerin meslek grupları arasında ayrım yapmaksızın mesleğe yeni başlayan ve deneyimleri daha az olan tüm sağlık çalışanlarını kendilerine daha yakın hissedip daha yakından gözlemlemiş olmaları, yapılan hataları daha çok fark etmiş olmalarından ve bu kişilerin bilgi ve deneyim eksikliklerinin az olmasından dolayı daha fazla hata yapabileceklerini düşünmelerinden olabileceği düşünülmektedir. Ayrıca öğrencilerin tıbbi hataların önlenebilir olduğunu düşünmeleri öğrencilerin hatalarla mücadele etmesini kolaylaştıracaktır.

Öğrencilerin tıbbi hataları azaltmaya yönelik önerileri sorulduğunda; "hastalara karşı daha duyarlı ve sorumlu davranılmalı/daha dikkatli ve özenli çalışılmalı", "personel sayısı artırılmalı" ve "denetlemeler artırılmalı/ciddi yaptırımlar uygulanmalı" önerilerinde bulunmuşlardır. Bodur ve ark yaptıkları bir çalışmada da öğrencilerin tamamına yakını hasta güvenliği konusunun derslerin içinde veya ayrı bir ders olarak müfredatta yer alması gerektiğini belirtmişlerdir [15]. Yine yapılan bir çalışmada sağlık çalışanları meslek hayatına başlandığında verilen oryantasyon eğitiminin tıbbi hataları önlemede etkili olduğunu belirtmişlerdir [21]. Araştırma sonuçları öğrencilerin tıbbi hatalar ve hasta güvenliğinin önemi hakkında farkındalıklarının olduğunu göstermektedir.

Öğrencilerin HTHEÖ toplam puan ortalaması $183,9 \pm 17,1$ olup (ölçeğin genel puan dağılım aralığı: 40200) öğrencilerin tıbbi hata yapma eğilimlerinin hem alt alanlarda hem de genelde düşük olduğu belirlenmiştir. Mankan, Turan ve Polat tarafından hemşirelik ve ebelik öğrencilerinin tıbbi hata yapma eğilimlerini incelemek amacıyla intörn hemşirelik ve ebelik öğrencileriyle yaptıkları araştırmada HTHEÖ toplam puan ortalaması 
200,62 $\pm 33,07$ (54-245 puan arası) olup düşük düzeyde tıbbi hata eğilimi saptanmıştır [23]. Kar ve Öztürk'ün hemşirelerin tıbbi hatalara eğilimlerinin belirlenmesi amacı ile yaptıkları bir çalışmada hemşirelerin HTHEÖ'inden aldıkları toplam puan ortalaması $4.80 \pm 0.21$ bulunmuş ve tıbbi hata yapma eğilimlerinin düşük olduğu belirlenmiştir [28]. Bu çalışmadaki puan ortalamasının çalışmamızdakinden daha yüksek bulunmuş olması, çalışan hemşirelerin öğrenci ebelerden daha fazla tıbbi hata konusunda farkındalıklarının olmasından kaynaklanabilir. Yine de çalışmamıza katılan öğrencilerin konu ile ilgili yeterli bilgi ve sorumluluğa sahip olduğunu, aldıkları teorik derslerin pratikte olumlu sonuçlar getirdiğini, hasta güvenliği kültürünü sağlamada dikkatli ve özenli olduklarını dolayısıyla öğrencilerin tıbbi hata yapma oranlarının azaldığını düşünmekteyiz. Çalışmamızın sonuçları olumlu bir sonuç olarak değerlendirilmekle birlikte öğrencilerin dişlanma veya okuldan ceza alma korkusu gibi nedenlerle ölçekte yer alan sorulara yüksek puanlar vermiş olmaları da imkân dâhilindedir.

Öğrencilerin HTHEÖ alt boyutlarından aldıkları puan ortalamaları sırasıyla ilaç ve transfüzyon uygulamaları: $83,3 \pm 7,7$ hastane enfeksiyonlar1: $55,0 \pm 6,0$, düşmelerin önlenmesi: $22,7 \pm 2,5$ ve iletişim: 22,7 $\pm 3,2$ 'dir. Hemşirelikte Tıbbi Hataya Eğilim Ölçeği toplam puan ortalaması: $183,9 \pm 17,1$ olup (ölçeğin genel puan dağ́lım aralığg:40-200) öğrencilerin tıbbi hata yapma eğilimlerinin hem alt alanlarda hem de genelde düşük olduğu belirlenmiștir (Tablo 3 ).

Ölçeğin alt boyutları incelendiğinde, "İlaç ve Transfüzyon Uygulamaları" alt boyut puan ortalamasının en yüksek olması $(83,3 \pm 7,7)$ öğrencilerin tıbbi hataya eğilimlerinin bu alt boyutta daha düşük; "düşmelerin önlenmesi" alt boyut puan ortalamasının ise diğer alt boyut puan ortalamalarına göre daha düşük olması $(22,7 \pm 2,5)$ öğrencilerin bu alana yönelik tıbbi hata eğilimlerinin daha yüksek olabileceğini düşündürmektedir. Literatürde konuyla ilgili yapılan çalışmalarda bildirilen ölçek ve alt boyut puan ortalamaları çalışmamızın bulgularıyla benzerlik göstermekte olup Yiğitbaș ve ark.'nın yaptıkları çalışmada hemşirelerin ölçekten aldıkları en yüksek puan ortalamasını ilaç uygulamaları ve transfüzyon uygulamaları $(4,76)$ alt grubunda, en düşük puan ortalamasını ise düşmeler $(4,50)$ alt grubunda aldıkları görülmüştür. Avşar ve ark çalışmasında da benzer bulgular (ilaç uygulamaları ve transfüzyon 4,69, düşmeler 4,47) elde edilmiş, Cebeci ve ark.'nın çalışmasında ise hemşirelerin alt boyutlara ilişkin aldıkları en düşük puan ortalamalarının hasta düşmelerin önlenmesi $(4,63)$ olduğu saptanmıştır [22, 29, 30]. Ancak literatürde Şahin ve Ö̈zdemir, Ersun ve ark, Özkan ve ark.'nın yaptıkları çalışmalarda hemşirelerin ölçeğin tüm alt boyutlarında düşük puan aldığı, "İlaç ve Transfüzyon Uygulamaları" alt boyut puan ortalamasının en düşük olduğu bu nedenle tıbbi hataya eğilimlerinin bu alt boyutta daha yüksek olduğu saptanmıştır [26, 31, 32]. Çalışma sonuçlarımız literatür ile tam olarak paralellik göstermemektedir. Çalışmamıza katılan öğrencilerin stajlarında ilaç ve transfüzyon uygulamaları sırasında serviste çalışan ebe ve hemşirelerin gözetiminde ve sorumluluğunda daha dikkatli uygulama yapıyor olması ve bununda oluşacak hataları önlemesinden kaynaklanıyor olabileceği düşünülmektedir.

Öğrencilerin okudukları sınıflara göre HTHEÖ Puan Ortalamalarının Dağılımı incelendiğinde, tüm sınıflarda ölçeğin alt alan puan ortalamalarının yüksek olduğu ancak "ilaç ve transfüzyon uygulamaları", "hastane enfeksiyonları", "düşmelerin önlenmesi” alt boyut puan ortalamaları arasındaki farkın sinıflar arasında istatistiksel olarak anlamlı olduğu (sırasıyla; $p=0,000$, $\mathrm{p}=0,000, \mathrm{p}=0,004)$, "iletişim" alt boyut puan ortalamaları arasındaki farkın ise sınırda olduğu bulunmuştur (Tablo 4). Yapılan ileri analizde bu farkın tüm alt alan puan ortalamalarında 2. sinıf ile 3. ve 4. siniflar arasında olduğu saptanmıştır. Çalışmamızda ikinci sınıfların tüm alanlarda hataya eğilimlerinin düşük olması bu sınıftaki ögrencilerin klinik uygulamaya daha az çıkmaları ve diğer sinıflara göre klinikte hastalara yönelik daha az girişim ve uygulama yapmalarından kaynaklanıyor olabileceği düşünülmektedir.

Çalışmaya katılan öğrencilerin yaş gruplarına göre ölçeğin "ilaç ve transfüzyon uygulamaları" ve "hastane enfeksiyonları" alt boyut puan ortalamaları arasında istatistiksel olarak anlamlı fark bulunmuştur. Yapılan ileri analizde bu farkın her iki alt alanda da $19-20$ ve 2233 yaş grupları arasında olduğu bulunmuştur. Öğrencilerin yaşları ilerledikçe sınıf numaralarının da büyüdüğü düşünülürse bu bulgular öğrencilerin sınıflarına ilişkin çıkan sonuçları desteklemektedir. Öğrencilerin mezun olunan lise, hasta güvenliği ve tıbbi hatalar konusunda eğitim alma durumu ölçeğin alt alan puan ortalamalarını etkilemediği saptanmıştır.

\section{Sonuç}

Ebelik öğrencilerinin hasta güvenliği konusundaki düşünceleri ve tıbbi hata yapma eğilimlerinin belirlenmesi amacıyla yapılan bu çalışmada; öğrencilerin yaklaşık üçte birinin klinik uygulamaları sırasında herhangi bir tıbbi hata yaptığı, büyük çoğunluğu bu hatalarını rapor ettiği ve en çok deneyimsiz sağlık çalışanlarının tıbbi hata yaptıklarını, tıbbi hataların en büyük nedenlerinin uzun çalışma saatlerine bağlı yorgunluk, stres ve mesleki eğitim yetersizliğine bağlı olduğunu düşündükleri, öğrencilerin HTHEÖ puan ortalaması yüksek olup tıbbi hata yapma eğilimlerinin düşük olduğu sonuçlarına ulaşılmıştır. $\mathrm{Bu}$ sonuçlara dayalı olarak;

- Ebelik bölümü öğrencilerine mesleğe başlamadan önce spesifik hedeflere yönelik eğitim programları uygulanması, hasta güvenliği ve tıbbi hataları önleme ayrı bir ders olarak müfredata konması, klinik uygulama denetimlerin sik yapılmasının yanı sıra niteliksel ve niceliksel değerlendirmelerle hataları önleme konusunda eğitim gereksinimleri belirlenmesi ve eğitimlerin sürekliliği ve güncelliğinin sağlanması,

- Sağlık çalışanlarını tıbbi hatalar ve hasta güvenliği ile ilgili farkındalıklarının arttırılması amacıyla düzenli hizmet içi eğitimlerin verilmesi, 
- Tıbbı hataların önlenmesi için hastanelerde etkin bir hata bildirim sisteminin kurulması, "Hasta ve Çalışan Güvenliğì" komite/kurularının oluşturulması, sağlık kuruluşlarının, çalışanlarını, yaptıkları ya da tanık oldukları tıbbi hataları uygun şekilde raporlamaya yönlendirmesi ve bu yönde çalışanları cesaretlendirmesi, - Tibbi hataları azaltmaya yönelik standart rehberlerin geliştirilmesi ve kullanılması,

- Ebelik ve diğer sağlık mesleği öğrencilerinin kliniklerde yaptıkları hata türleri ve nedenlerine yönelik daha kapsamlı ve güçlü kanıtlar oluşturabilecek gözlemsel, deneysel ve kalitatif çalışmaların yapılmas önerilebilir.

\section{Araștırmanın sınırlılıkları}

Çalışmanın tek bir üniversitede yapılmış olması ve araştırmaya katılan öğrencilerin bildirimine dayanması araştırmanın sınırlılıklarını oluşturmaktadır. $\mathrm{Bu}$ nedeniyle araştırma sonuçları tüm ebelik bölümü öğrencilerine genellenemez.

Bu çalışma 03-05 Mayıs 2018 tarihlerinde Amasya 5. Uluslararası ve 9. Ulusal Ebelik Öğrencileri Kongresi'nde bildiri olarak sunulmuştur. Çalışmayı maddi olarak destekleyen kişi/kuruluş yoktur ve yazarların herhangi bir çıkar dayalı ilişkisi yoktur.

\section{Referanslar}

1. World Health Organization, WHO Patient Safety Curriculum Guide: Multi-Professional Edition. World Health Organization. http://apps.who.int/iris/bitstream/10665/44641/1/9789241501958_e ng.pdf, 2011 (accessed 02.01.2018)

2. Linda, T, Kohn, LT, Corrigan, JM, Donaldson, MS. To err is human: Building a safer health system.

(https://www.nap.edu/catalog/9728/to-err-is-human-building-asafer-health-system (accessed 03.01.2019).

3. World Health Organization. WHO Patient Safety: Making health care safer. World Health Organization. http://apps.who.int/iris/bitstream/10665/255507/1/WHO-HIS-SDS2017.11-eng.pdf, 2017 (accessed 0302.01.2018).

4. Valsmoradi, M, Salsali, M, Marck, P, Patient safety: Nursing students perspectives and the role of nursing education to provide safe care, International Nursing Review, 2011, 58, 434-442.

5. Xianqiong, F, Bobay, K, Weiss, M. Patient safety culture in nursing: A dimensional concept analysis, Journal of Advanced Nursing, 2008 63(3), 310-319.

6.Perneger, TV, A research agenda for patient safety, International Journal for Quality in Health Care, 2006, 18(1), 1-3.

7. World Health Professions Alliance. Patient safety: world health professions alliance fact sheet. http://www.whpa.org/factptsafety.pdf, 2002 (accessed 02.01.2018).

8. Alfredsdottir, H, Bjornsdottir, K, Nursing and patient safety in the operating room, Journal of Advanced Nursing, 2008, 61(1), 29-37.

9. Hergül, FK, Özbayır, T, Gök, F, Ameliyathanede hasta güvenliği: Sistematik derleme, Pamukkale Tip Dergisi, 2016, 9(1), 87-98.

10. Gökdoğan, F, Yorgun S, Sağllk hizmetlerinde hasta güvenliği ve hemşireler, Anadolu Hemşirelik ve Sağllk Bilimleri Dergisi, 2010 13(2), 53-59.

11. Farquhar, M, Sharp, BAC, Clancy, CM, Patient safety in nursing practice, Association of periOperative Registered Nurses Journal, 2007, 86, 455-457.

12. Nabilou, B, Feizi, A, Seyedin, H, Patient safety in medical education: Students' perceptions, knowledge and attitudes. Public Library of Science, 2015, 10(8), 1-8

13. Reid-Searl, K, Moxham, L, Happell, B, Enhancing patient safety: The importance of direct supervision for avoiding medication errors and near misses by undergraduate nursing students. International Journal of Nursing Practice, 2010, 16, 225-232.
14. Ward, DJ. Infection control in clinical placements: Experiences of nursing and midwifery students, Journal of Advanced Nursing, 2010, 66(7), 1533-1542.

15. Bodur, S, Filiz, E, Çimen, A, Kapçı, C, Ebelik ve hemşirelik son sınıf öğrencilerinin hasta güvenliği ve tıbbi hatalar konusundaki tutumu, Genel Tip Dergisi, 2012, 22(2), 37-42.

16. Sharif, F, Masoumi, S.A, Qualitative study of nursing student experiences of clinical practice, BioMed Central Nursing, 2005, 4, 610

17. Sammer, CE, Lykens, K, Singh, KP, Mains, DA, Lackan, NA, What is patient safety culture? A review of the literature, Journal of Nursing Scholarship, 2010, 42(2), 156-165.

18. Cebeci, F, Karazeybek, E, Sucu, DG, Öğrenci hemșirelerin hastane uygulamaları sırasında tanık oldukları tıbbi hata durumları, Gümüşhane Üniversitesi Sağllk Bilimleri Dergisi, 2014, 3(2), 736748.

19. Aston, SJ, Rheault, W, Arenson, C, Tappert, SK, Stoecker, J, Orzoff, J, Galitski, H, Mackintosh, S. Interprofessional education: A review and analysis of programs from three academic health centers, Academic Medicine, 2012, 87(7), 949-955

20. Özata, M, Altunkan, H. Hemşirelikte tıbbi hataya eğilim ölçeğinin geliştirilmesi ve geçerlilik güvenilirlik analizinin yapılması. II. Uluslararası Sağlıkta Kalite ve Performans Kongresi Bildiriler Kitabı, Ankara: Sağlık Bakanlığı Yayınları, 2010

21. Yıldız, T, Eriten, G, Erdem, İ, Gökay, NS, Kulaç, M, Alp, R, Mezuniyetin ve profesyonel sağlık personeli olarak çalışmanın hasta güvenliği bilinci üzerine etkileri, Kafkas Tip Bilimleri Dergisi, 2012, 2(3), 94-98.

22. Yiğitbaş, Ç, Oğuzhan, H, Tercan, B, Bulut, A, Bulut A, Hemşirelerin malpraktis ile ilgili algı, tutum ve davranışları, Anadolu Kliniği, 2016, 21(3), 207-214.

23. Mankan T, Bahçecioğlu GT, Polat H. Hemşirelik ve ebelik öğrencilerinde malpraktis, Sağlık Bilimleri ve Meslekleri Dergisi, 2017, 4(2), 98-104.

24. Alemdar, DK, Aktaş, YY. Türkiye'de hemşirelik hizmetlerinde tıbbi hata türleri ve nedenleri, TAF Preventive Medicine Bulletin, 2013, 12(3), 307-314

25. Özata, M, Altunkan, H. Hastanelerde tıbbi hata görülme sıklıkları, tıbbi hata türleri ve tıbbi hata nedenlerinin belirlenmesi: Konya örneği, Tıp Araştırmaları Dergisi, 2010, 8(2), 100-111.

26. Şahin, ZA, Özdemir, FK, Hemșirelerin tıbbi hata yapma eğilimlerinin incelenmesi, Hemşirelikte Eğitim ve Araştırma Dergisi, 2015, 12(3), 210-214.

27. Kahriman, İ, Öztürk, H, Evaluating medical errors made by nurses during their diagnosis, treatment and care practices, Journal of Clinical Nursing, 2016, 25(19-20), 2884-2894.

28. Kar, G, Öztürk, Ö, Hemşirelerin tıbbi hata eğilimlerine yönelik bir çalışma, Sağlık Bilimleri ve Meslekleri Dergisi, 2014, 1(1), 17-27.

29. Cebeci, F, Gürsoy, E, Tekingündüz, S, Hemșirelerin tıbbi hata yapma eğilimlerinin belirlenmesi. Anadolu Hemşirelik ve Sağlık Bilimleri Dergisi, 2012, 15(3),188-196.

30. Avşar, G, Atabek, AA, Karaman, ZÖ, Determining the level of tendency in malpractice of nurses: A hospital sample, Sağlık Bilimler ve Meslekleri Dergisi, 2016, 3(2), 115-122.

31. Özkan, S, Kocaman, G, Öztürk, C, Seren, S, Frequency of pediatric medication administration errors and contributing factors. Journal of Nursing Care Quality, 2011, 26(2), 136-143.

32. Ersun, A, Bașbakkal, Z, Yardımcı, F, Muslu, G, Beytut, D, Çocuk hemșirelerinin tıbbi hata yapma eğilimlerinin incelenmesi, Ege Üniversitesi Hemşirelik Fakültesi Dergisi, 2013, 29(2), 33-45.

http://edergi.cbu.edu.tr/ojs/index.php/cbusbed isimli yazarın CBU-SBED başlıklı eseri bu Creative Commons Alıntı-Gayriticari4.0 Uluslararası Lisansı ile lisanslanmışıtır.

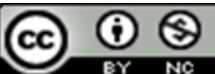

